Lepr Rev (1989) 60, 39-44

\title{
The current state of leprosy control activities in Sri Lanka
}

\author{
D R DEWAPURA \\ Anti-leprosy Campaign, 385 Deans Road, Colombo, Sri Lanka
}

Accepted for publication 12 October 1988

\begin{abstract}
Summary In Sri Lanka the overall prevalence of leprosy was $0 \cdot 14$ per 1000 population and the incidence 0.07 per 1000 population at the end of 1987 . Although the endemicity is low in the island, disease transmission has not yet been achieved as the annual detection of new cases and the child rate has been gradually rising. The major activities of the leprosy control programme are case-finding, treatment and defaulter retrieval, health education, rehabilitation and training. The field programme is implemented through 15 specially trained paramedical workers. In addition there are 5 medical officers attached to the Anti-leprosy Campaign. The Director of the Anti-leprosy Campaign is in overall charge of the National Leprosy Programme and is also project manager for the Sri Lanka Emmaus Leprosy Control Project.
\end{abstract}

\section{Introduction}

Sri Lanka, a small island in the Indian Ocean close to South India, has an area of 65,610 square kilometres. Its length is 445 kilometres, breadth $225 \cdot 3$ kilometres, and it has a population of $16 \cdot 34$ million.

There is a belt of high prevalence of leprosy ranging from $0 \cdot 3$ per 1000 population to $0 \cdot 13$ per 1000 in the Western and Southern Provinces extending to the Eastern Province along the coast, with endemic foci in certain districts. The Northern Province is moderately endemic. The rest of the country has a very low endemicity with prevalence rates below 0.07 per 1000 population.

Though leprosy has a low degree of endemicity in the country, interruption of disease transmission has not yet been achieved. This observation is based on the following indicators:

New cases detected annually have risen gradually from 329 in 1947 to 1194 in 1986, but there was a decrease to 1074 in 1987 probably because the case-finding programme, planned was not fully implemented.

Child rate which was only $5 \cdot 4 \%$ in 1959 has increased to $20 \cdot 4 \%$ in 1987 .

\section{Situation analysis}

The statistics at the end of 1987 showed that the overall prevalence in the island was $0 \cdot 14$ per 1000 population and the incidence 0.07 per 1000 population. During the first half of 1987 on the recommendation of a WHO Consultant (who was in Sri Lanka to review the National Leprosy Control Programme) updating of patients' registers were done and many cases were taken out of the 


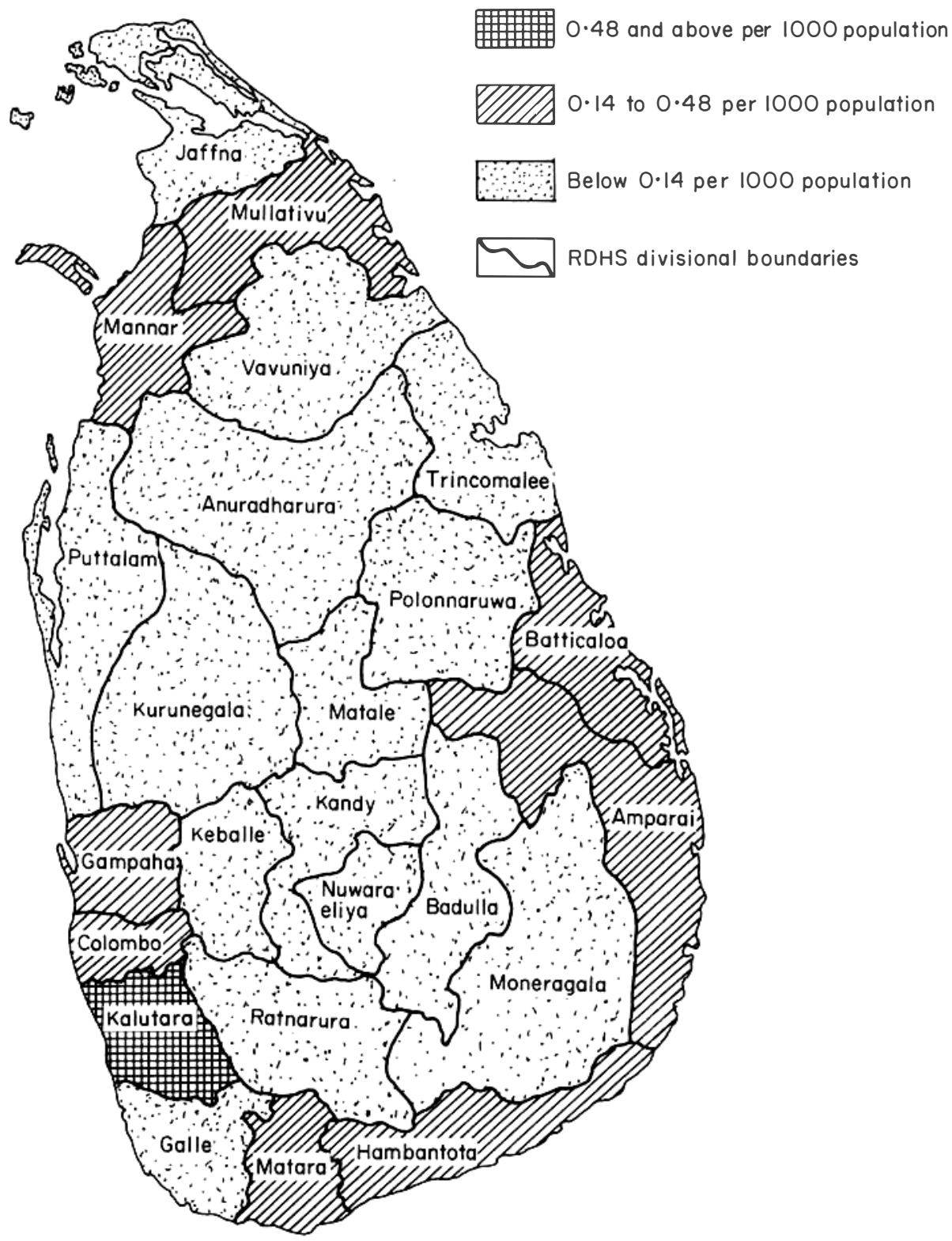

Figure 1. Endemicity of leprosy in Sri Lanka by Regional Director of Health Services Divisions on 31.12.87. 
Table 1. Registered cases and new cases by Provinces as on 31.12 .87

\begin{tabular}{lccc}
\hline Regions & $\begin{array}{c}\text { Population } \\
1987\end{array}$ & $\begin{array}{c}\text { Registered } \\
1987\end{array}$ & $\begin{array}{c}\text { New cases } \\
1987\end{array}$ \\
\hline Western & $4,238,000$ & 4879 & 537 \\
Southern & $2,115,000$ & 1102 & 124 \\
Eastern & $1,148,000$ & 355 & 109 \\
Sabaragamuwa & $1,608,000$ & 297 & 50 \\
North Western & $1,910,000$ & 437 & 99 \\
Northern & $1,249,000$ & 441 & 38 \\
Central & $2,095,000$ & 208 & 45 \\
North Central & 952,000 & 228 & 41 \\
UVA & $1,007,000$ & 147 & 31 \\
\hline Total & $16,322,000$ & $8094 *$ & 1074 \\
& & & \\
\hline
\end{tabular}

* This has been made up as follows:

Active cases

2305

Cases under surveillance $\quad 4531$

Cases for care only 1258

8094

Table 2. Prevalence rates and incidence rates by Provinces as on 31.12.87

\begin{tabular}{lccc}
\hline Province & $\begin{array}{c}\text { Total no. of } \\
\text { cases* }\end{array}$ & $\begin{array}{c}\text { Prevalence } \\
\text { rate }\end{array}$ & $\begin{array}{c}\text { Incidence } \\
\text { rate }\end{array}$ \\
\hline Western & 4879 & $0 \cdot 30$ & $0 \cdot 13$ \\
Southern & 1102 & $0 \cdot 13$ & $0 \cdot 06$ \\
Eastern & 355 & $0 \cdot 17$ & $0 \cdot 09$ \\
Northern & 441 & $0 \cdot 12$ & $0 \cdot 03$ \\
North Central & 228 & 0.07 & 0.04 \\
North Western & 437 & 0.07 & 0.05 \\
UVA & 147 & $0 \cdot 05$ & 0.03 \\
Sabaragamuwa & 297 & 0.05 & 0.03 \\
Central & 208 & $0 \cdot 04$ & $0 \cdot 02$ \\
\hline
\end{tabular}

* Registered cases, 8094. 
Table 3. Total number of active cases by ethnic groups as on 31.12 .87

\begin{tabular}{lrrrrrrrrr}
\hline & \multicolumn{3}{c}{ Multibacillary } & & \multicolumn{3}{c}{ Paucibacillary } \\
\cline { 2 - 3 } Race & M & F & Total & & M & F & Total & Total \\
\hline Sinhalese & 466 & 163 & 629 & & 602 & 464 & 1066 & 1695 \\
Cey. Tamil & 96 & 55 & 151 & 198 & 227 & 425 & 576 \\
Cey. Moors & 09 & 04 & 13 & 10 & 9 & 19 & 32 \\
Malays & - & - & - & - & - & - & - \\
Burghers & - & - & - & - & - & - & - \\
Ind. Tamil & - & - & - & - & - & - & - \\
Ind. Moors & - & - & - & - & - & - & - \\
\hline Total & 571 & 222 & 793 & 811 & 701 & 1512 & 2305 \\
\hline
\end{tabular}

Table 4. Total number of active cases by age groups as on 31.12 .87

\begin{tabular}{|c|c|c|c|c|c|c|c|}
\hline \multirow{2}{*}{$\begin{array}{l}\text { Age } \\
\text { group } \\
\text { (years) }\end{array}$} & \multicolumn{3}{|c|}{ Multibacillary } & \multicolumn{3}{|c|}{ Paucibacillary } & \multirow[b]{2}{*}{ Total } \\
\hline & $\mathbf{M}$ & $\mathrm{F}$ & Total & M & $\mathrm{F}$ & Total & \\
\hline $0-4$ & - & - & - & 12 & 07 & 19 & 19 \\
\hline $5-9$ & 02 & 02 & 04 & 54 & 52 & 106 & 110 \\
\hline $10-14$ & 13 & 09 & 22 & 90 & 86 & 176 & 198 \\
\hline $15-24$ & 67 & 16 & 83 & 154 & 146 & 300 & 383 \\
\hline $25-39$ & 144 & 58 & 202 & 174 & 148 & 322 & 524 \\
\hline $40-49$ & 108 & 43 & 151 & 130 & 122 & 252 & 403 \\
\hline $50-59$ & 103 & 39 & 142 & 86 & 63 & 149 & 291 \\
\hline $60-69$ & 70 & 41 & 111 & 71 & 53 & 124 & 235 \\
\hline $70+$ & 64 & 14 & 78 & 40 & 24 & 64 & 142 \\
\hline Total & 571 & 222 & 793 & 811 & 701 & 1512 & 2305 \\
\hline
\end{tabular}

Table 5. Total number of new cases detected in 1987 by age groups

\begin{tabular}{|c|c|c|c|c|c|c|c|}
\hline \multirow{2}{*}{$\begin{array}{l}\text { Age } \\
\text { group } \\
\text { (years) }\end{array}$} & \multicolumn{3}{|c|}{ Multibacillary } & \multicolumn{3}{|c|}{ Paucibacillary } & \multirow[b]{2}{*}{ Total } \\
\hline & $\mathbf{M}$ & $\mathrm{F}$ & Total & $\mathbf{M}$ & $\mathrm{F}$ & Total & \\
\hline $0-4$ & - & - & - & 06 & 03 & 09 & 09 \\
\hline $5-9$ & - & 01 & 01 & 38 & 45 & 83 & 84 \\
\hline $10-14$ & 02 & - & 02 & 69 & 55 & 124 & 126 \\
\hline $15-24$ & 08 & 09 & 17 & 61 & 79 & 140 & 157 \\
\hline $25-39$ & 32 & 15 & 47 & 123 & 98 & 221 & 268 \\
\hline $40-49$ & 16 & 06 & 22 & 52 & 62 & 114 & 136 \\
\hline $50-59$ & 23 & 05 & 28 & 57 & 61 & 118 & 146 \\
\hline $60-69$ & 15 & 07 & 22 & 44 & 37 & 81 & 103 \\
\hline $70+$ & 06 & 01 & 07 & 27 & 11 & 38 & 45 \\
\hline Tot & 102 & 44 & 146 & 477 & 451 & 928 & 1074 \\
\hline
\end{tabular}


'active' cases register, hence there was a drop in prevalence rate of 0.6 per 1000 population in 1986 to $0 \cdot 14$ per 1000 population in 1987 . The incidence was the same in 1986 and 1987 respectively.

Statistics of all the island as at 31.12 .87 :

Total number of active cases

Total number of surveillance cases

Total number of 'care' cases

Of active cases:

Multibacillary

Paucibacillary

$65 \cdot 5 \%$

Among active cases:

Males

$59 \cdot 9 \%$

Females

$40 \cdot 1 \%$

Children below 15 years of age

$14 \cdot 2 \%$

New cases were detected mainly by:

Referrals

$54 \cdot 5 \%$

Surveys

$31 \cdot 4 \%$

Contact examination

$10 \cdot 7 \%$

Self-reporting

Among new cases detected during 1987:

Multibacillary

Paucibacillary

Children below 15 years of age

$97.96 \%$ of new cases detected were without Grade II and III deformities.

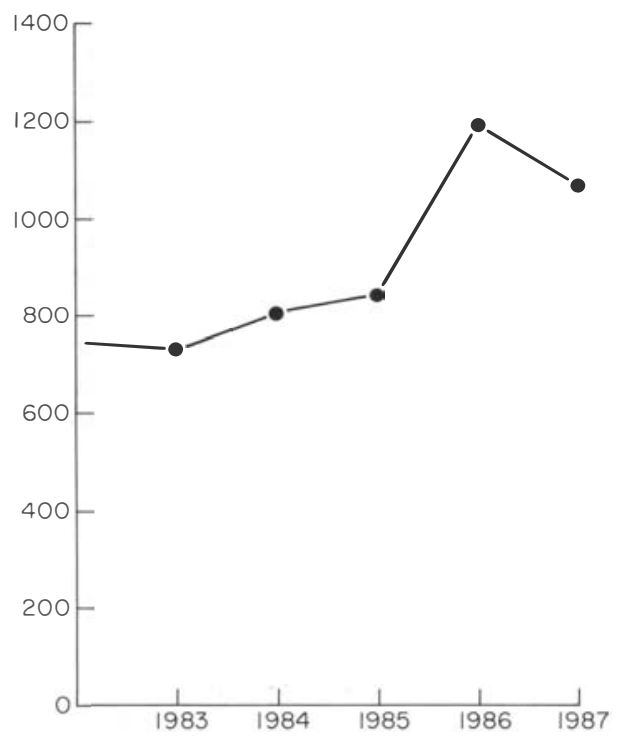

Figure 2. New cases detected since 1983. 
Table 6. Total number of new cases detected in 1987 below and above 15 years of age

\begin{tabular}{|c|c|c|c|c|c|c|c|}
\hline \multirow[b]{2}{*}{ Age } & \multicolumn{3}{|c|}{ Multibacillary } & \multicolumn{3}{|c|}{ Paucibacillary } & \multirow[b]{2}{*}{ Total } \\
\hline & $\mathbf{M}$ & $\mathrm{F}$ & Total & $\mathbf{M}$ & $\mathrm{F}$ & Total & \\
\hline-15 & 02 & 01 & 03 & 113 & 103 & 216 & 219 \\
\hline+15 & 100 & 43 & 143 & 364 & 348 & 712 & 855 \\
\hline Total & 102 & 44 & 146 & 477 & 451 & 928 & 1074 \\
\hline
\end{tabular}

The major activities of the Leprosy Control Programme are:

Case finding:

Active methods

Passive methods

Treatment and defaulter retrieval

Health education

Rehabilitation

Training

All cases on the Active Case Register are on multidrug therapy. The treatment regimen advocated by the WHO is being adhered to and carried out at 81 treatment centres throughout the country. Multidrug therapy commenced in 1982.

The field programme is implemented through 15 specially trained public health inspectors (paramedical workers). These public health inspectors are responsible for the above activities in their control areas (the country being divided into fifteen control areas). They integrate at the periphery with the primary health care workers and with voluntary workers. In addition to the 15 public health inspectors there are 5 medical officers attached to the leprosy campaign: 2 in Colombo at the Central Leprosy Clinic which is the headquarters of the Leprosy Control Programme, 1 as the Regional Medical Officer of the Southern province, and the other 2 are in charge of the 2 leprosy hospitals situated in the Western and Eastern Provinces. The former was constructed in 1706 during the period of Dutch occupation and the latter in 1921 during the period of British occupation of the country.

As government policy no new admissions have been made to the 2 hospitals since 1977 except those needing temporary hospitalization for reactions and ulcers.

The Director of the Leprosy Control Programme is in overall charge and is the National Programme Manager.

Emmaus Suisse a private voluntary organization assists and augments the National Leprosy Control Programme, in addition (since 1981) a model pilot project to intensify case detection was implemented in 1 district in the Western Province. This is being extended to 4 other districts in the Western and Southern Provinces now. 